\title{
Opposite sexual dimorphism of 3,4-dihydroxyphenylalanine decarboxylase in the kidney and small intestine of mice
}

\author{
Andrés J López-Contreras ${ }^{1}$, Jesús D Galindo ${ }^{1}$, Carlos López-García ${ }^{1}$, Maria T Castells ${ }^{2}$, \\ Asunción Cremades $^{3}$ and Rafael Peñafiel ${ }^{1}$ \\ Departments of ${ }^{1}$ Biochemistry and Molecular Biology B and Immunology, ${ }^{2}$ Cell Biology and ${ }^{3}$ Pharmacology, Faculty of Medicine, University of Murcia, \\ Campus de Espinardo, 30100 Murcia, Spain \\ (Correspondence should be addressed to R Peñafiel; Email: rapegar@um.es)
}

\begin{abstract}
3,4-Dihydroxyphenylalanine decarboxylase (DDC; also known as L-amino acid decarboxylase) is involved in the synthesis of dopamine, norepinephrine, and serotonin, and also acts as an androgen receptor co-regulator protein. In contrast to other amino acid decarboxylases that are modulated by sex hormones, little is known about the influence of these hormones on DDC regulation. In the present work, we studied the influence of gender in the expression of DDC in different mouse tissues. Among the different organs studied, including brain, liver, kidney, intestine, heart, adrenal gland, and skeletal muscle, only kidney and small intestine showed a sex-dependent dimorphism in DDC expression. In the kidney, levels of DDC activity, DDC mRNA, and protein were remarkably higher in females than in males. On the contrary, in the small intestine, male mice displayed higher levels of DDC activity than females but they
\end{abstract}

did not correlate precisely with mRNA levels. This dimorphism was dependent on androgens, since male castration and treatment of female mice with testosterone propionate, oppositely affected DDC levels in kidney and small intestine. However, estrogen ablation or treatment with estradiol did not significantly affect DDC activity in these tissues. Immunocytochemical analysis revealed that DDC was mainly located in the proximal straight tubular cells of the kidney and in the cytoplasm of enterocytes. These data and the fact that renal DDC inversely correlated with renal sodium reabsorption suggest that renal and intestinal gender dimorphism in DDC could be related to sexrelated differences in sodium balance observed between males and females.

Journal of Endocrinology (2008) 196, 615-624

\section{Introduction}

The enzymatic synthesis of the biogenic amines dopamine, histamine, putrescine, and agmatine involves the decarboxylation of the corresponding amino acid by its cognate amino acid decarboxylase (Hayashi et al. 1990a,b, Sandmeier et al. 1994, Viguera et al. 1994, Zhu \& Juorio 1995, Pegg 2006, Kidron et al. 2007). More specifically, the key step in the formation of the aromatic amines dopamine, epinephrine, and norepinephrine is catalyzed by a single enzyme named 3,4-dihydroxyphenylalanine (DOPA) decarboxylase (DDC, EC 4.1.1.28) since it can convert L-DOPA into dopamine (Christenson et al. 1972, Zhu \& Juorio 1995, Berry et al. 1996). Because this enzyme may also decarboxylate other aromatic amino acids, such as 5-hydroxytryptophan, tryptophan, phenylalanine, and tyrosine, producing their corresponding amines 5-hydroxytryptamine, tryptamine, phenylethylamine, and tyramine, it is also named aromatic L-amino acid decarboxylase (AADC).

The enzyme has been characterized from different mammalian tissues, especially brain, liver, kidney, pancreas, adrenal glands, and placenta (Fellman 1959, Lovenberg 1971, Borri Voltattorni et al. 1979, Lindström 1986, Hayashi et al. 1990a,b, Siaterli et al. 2003). The renal enzyme from pig and guinea pig has been extensively purified and its kinetic and structural properties have been thoroughly studied (O'Learly \& Baughn 1977, Minelli et al. 1979, Dominici et al. 1985, 1993). cDNAs from rat and human DDC have been cloned and sequenced (Ichinose et al. 1989, Tanaka et al. 1989) and the structure and sequence of other mammalian DDC genes, including murine DDC, are already available from GeneBank databases. Most studies on the physiological function of the DDC have been carried out on the enzyme from neuronal tissues where the decarboxylase is clearly related to the formation of biogenic active amines that act as neurotransmitters or neuromodulators (Molinoff \& Axelrod 1971, Carlsson 1987). In extra-neural tissues, the enzyme activity has been associated with both amine synthesis and catabolism of aromatic amino acids (Rahman et al. 1981), and most of the in vivo studies on the peripheral DDC have focused mainly on its inhibition in order to improve L-DOPA therapy in Parkinson's disease (Da Prada 1985). However, several studies 
have pointed out that the enzyme may participate in the regulation of different physiological processes in peripheral tissues. Thus, in the rat kidney, it has been suggested that tubular DDC and its product dopamine may affect sodium absorption by renal epithelial cells (Bertorello et al. 1988, Vieira-Coelho et al. 2000). In the mouse, the high DDC activity found in the pancreatic islets has been related with a stimulatory effect on insulin secretion (Lindström 1986). Dopamine and serotonin, DDC products, play crucial roles in the behavior and development of insects (Hodgetts \& O'Keefe 2006), having been demonstrated that DDC could also participate in the regulation of Drosophila lifespan (De Luca et al. 2003). Interestingly, it has been shown that DDC binds and enhances the transcriptional activity of androgen receptors (AR; Wafa et al. 2003), which indicates that DDC may exert actions independently of its catalytic activity. In addition, other so-far-undetermined functions cannot be excluded.

The properties and regulatory mechanisms of the mammalian amino acid decarboxylases that generate biogenic amines have been extensively studied, especially for those decarboxylating histidine and ornithine (Moya-Garcia et al. 2004, Pegg 2006). Both enzymes exhibit a sexual dimorphic pattern in different murine tissues. In this regard, it is known that there is a marked sexual extra-genital dimorphism in the kidney, liver, and skeletal muscle in several mouse strains, affecting many different proteins (Bardin \& Catterall 1981). In particular, renal ornithine decarboxylase (ODC) activity is remarkably higher in males than in females, and the treatment of females with testosterone elicits a dramatic increase of ODC activity in renal tissue (Henningsson et al. 1978, Melatinou et al. 1987, Sánchez-Capelo et al. 1994), mediated by transcriptional, translational, and post-translational mechanisms (Seely et al. 1982, Kontula et al. 1984, Berger \& Watson 1989). On the other hand, renal histidine decarboxylase is up-regulated by estrogens and repressed by androgens (Grahn et al. 1973, Middleton et al. 1987, Middleton \& Bulfield 1988). In contrast, little is known about the influence of sex hormones on the regulation of DDC in murine tissues. The possible existence of sexual dimorphism in catecholamine metabolism could be of potential interest to explain gender-dependent differences in response to stress. In this respect, it is widely accepted that a better knowledge of the biochemical and physiological differences between sexes may be of great relevance for the prevention, diagnosis, and treatment of many human diseases (Marts \& Keitt 2004).

In the present work, we have studied the influence of sex on DDC activity in different mouse tissues. We demonstrate, for the first time, the existence of a marked and opposite sexual dimorphism of DDC in the intestine and kidney of mice, affecting DDC activity and protein. Moreover, we postulate that this DDC dimorphism may have physiological relevance in sodium homeostasis, mainly through the modulation of sodium absorption by the kidney.

\section{Materials and Methods}

\section{Animals and treatments}

Immature and adult Swiss CD1 mice were bred in the animal house facilities of the University of Murcia. Before weaning, pups were maintained with dams in individual cages. After weaning, animals were fed with standard chow (UAR A03, Panlab, Barcelona, Spain) and water ad libitum. The sodium and potassium content of this diet were 2500 and $5600 \mathrm{mg} / \mathrm{kg}$ respectively. Animals were maintained at $22{ }^{\circ} \mathrm{C}$ ambient temperature and 50\% relative humidity under a controlled $12 \mathrm{~h}$ light:12 h darkness cycle (lights on at $0800 \mathrm{~h}$ ). To collect urine, mice were kept in metabolic boxes for 4 days and urine collected daily. Several groups of control and treated mice were used in different experiments. Two groups of 3-monthold male mice (weighing 38-41 g) and female mice (weighing 27-30 g) were gonadectomized under ether anesthesia and used 15 days after surgery. A subgroup of castrated males was injected with $17 \beta$-estradiol benzoate $(50 \mu \mathrm{g} / \mathrm{kg}$ body weight, sc, daily) and mice were killed after 2 weeks of treatment. Another group of intact male mice was treated with the antiandrogen flutamide; mice were injected sc with flutamide ( $25 \mathrm{mg} / \mathrm{kg}$ body weight, 4 injections, $12 \mathrm{~h}$ apart) and killed $48 \mathrm{~h}$ after the first injection. Two groups of intact adult females were injected with testosterone propionate under two different schedules: in the first subgroup, a single sc injection of testosterone $(20 \mathrm{mg} / \mathrm{kg}$ body weight) was given at $0900 \mathrm{~h}$ and the mice were killed 24 or $48 \mathrm{~h}$ after injection; and in the second subgroup, animals were injected with testosterone propionate $(20 \mathrm{mg} / \mathrm{kg}$ body weight) every other day and killed after 2 weeks of treatment. In all cases, animals were killed by cervical dislocation and the organs were quickly removed, weighed, and processed. In the case of the intestine, tissues were cut into the desired segments, washed thrice with cold $0.9 \%$ saline solution before homogenization. A $2 \mathrm{~cm}$ segment of the small intestine adjacent to the pyloric sphincter was taken as duodenum, a $2 \mathrm{~cm}$ segment of the middle portion of the small intestine was taken as jejunum, and a $2 \mathrm{~cm}$ segment of the small intestine adjacent to the cecum was taken as ileum. Procedures involving animals and their care were conducted in conformity with the institutional guidelines of the University of Murcia that are in compliance with national laws and policies (RD 1201/2005).

\section{Measurement of DDC activity}

For enzyme determination, tissues were homogenized with the aid of a Polytron homogenizer in a buffer containing $25 \mathrm{mM}$ Tris $(\mathrm{pH} 7 \cdot 2), 2 \mathrm{mM}$ dithiothreitol, $0 \cdot 1 \mathrm{mM}$ pyridoxal phosphate, $0 \cdot 1 \mathrm{mM}$ EDTA, and $0 \cdot 25 \mathrm{M}$ sucrose (1:5, w:v). The homogenate was centrifuged at $12000 \boldsymbol{g}$ for $20 \mathrm{~min}$, and DDC activity was determined in the supernatant by measuring ${ }^{14} \mathrm{CO}_{2}$ release from $1-{ }^{14} \mathrm{C}$ DOPA, using a protocol similar to the one used for measuring ODC activity (Bastida et al. 2005). In brief, the incubation mixture contained $20 \mathrm{mM}$ Tris $\mathrm{pH}$ 
$7 \cdot 2,0 \cdot 1 \mathrm{mM}$ pyridoxal phosphate, $0 \cdot 1 \mathrm{mM}$ EDTA, $2 \mathrm{mM}$ dithiothreitol, $1.30 \mathrm{mM}$ L-DOPA, and $0.03 \mathrm{mM}$ DOPA, DL3,4-alanine $1-{ }^{14} \mathrm{C}\left({ }^{14} \mathrm{C}\right.$-DOPA, American Radiolabeled Chemicals Inc., St Louis, MO, USA, specific activity $54 \mathrm{mCi} / \mathrm{mmol}$ ) in a total volume of $62.5 \mu \mathrm{l}$. The samples were incubated at $37^{\circ} \mathrm{C}$ for $30 \mathrm{~min}$ in closed reaction tubes with a rubber cap carrying two discs of Whatman paper containing $1 \mathrm{M}$ benzethonium hydroxide. The reaction was stopped by adding $0.5 \mathrm{ml}$ of $2 \mathrm{M}$ citric acid. The discs were transferred to scintillation vials containing $10 \mathrm{ml}$ scintillation fluid and counted. Activity was expressed as nmol $\mathrm{CO}_{2}$ produced per hour and per $\mathrm{g}$ of wet weight tissue. DDC activity assay was highly reproducible and ${ }^{14} \mathrm{CO}_{2}$ release was completely inhibited by $1 \mu \mathrm{M}$ benserazide or carbidopa, two well-known DDC inhibitors.

$\mathrm{Na}^{+}$and $\mathrm{K}^{+}$analysis in urine

$\mathrm{Na}^{+}$and $\mathrm{K}^{+}$contents of urine were determined using a flame photometer (Instrumentation Laboratory, Milano, Italy). Urine was collected daily from metabolic cages. When possible, urine was also collected directly from the urinary bladder, after killing the animals. Urine samples were diluted with doubled distilled deionized water and $\mathrm{Na}^{+}$and $\mathrm{K}^{+}$contents measured by flame photometry. Results were expressed as $\mathrm{mEq} \mathrm{Na}^{+}$or $\mathrm{K}^{+}$per mmol of creatinine. Creatinine was determined by the Jaffe method (Peñafiel et al. 1983).

\section{Quantitative real-time RT-PCR}

Gene expression was measured by both semiquantitative and quantitative RT-PCR, using SYBR Green PCR Master Mix and a Real-Time PCR equipment (Applied Biosystems, Foster City, CA, USA), according to the manufacturer's protocols. Total RNA was extracted from tissues with GenElute mammalian total RNA Miniprep kit (Sigma Chemical Co.), following the manufacturer's instructions. Total RNA was reverse transcribed using oligo $(\mathrm{dT})_{18}$ as primer and MMLV reverse transcriptase (Sigma Chemical Co). For semiquantitative RT-PCR analysis, the cDNAs were amplified by means of Taq polymerase (Sigma Chemical Co.) using specific primer pairs within the linear range for each gene product. Amplified products were resolved by electrophoresis in $2 \%$ agarose gel containing $40 \mathrm{mM}$ Tris/acetate and $1 \mathrm{mM}$ EDTA (TAE buffer, $\mathrm{pH} 8 \cdot 0)$ in a horizontal slab gel apparatus using $1 \times \mathrm{TAE}$ buffer. The gel was stained with ethidium bromide $(0 \cdot 2 \mu \mathrm{g} / \mathrm{ml}$ for $15 \mathrm{~min}$ ), followed by destaining in water, photographed by u.v. transilumination using a Gel Doc system camera (Bio-Rad Hercules, CA, USA), and the bands quantified using the MultiAnalyst software (Bio-Rad). Primers used (from SigmaGenosys) for the semiquantitative analysis of the genes analyzed were DDC, forward 5' -TCGAGAAGATAATCATGCCA-3' and reverse $5^{\prime}$-TTCTACAGAGGAATGCGCCT-3'; and $\beta$-actin, forward $5^{\prime}$-TGCGTCTGGACCTGGCTG- $3^{\prime}$ and reverse $5^{\prime}$-CTGCTGGAAGGTGGACAG-3', which produce amplicons of 409 and $535 \mathrm{bp}$ respectively. For real-time
RT-PCR, the primers used for amplification were: DDC, forward $5^{\prime}$-GGACTAAAGTTATCCGCCAG- $3^{\prime}$ and reverse $5^{\prime}$-TTCTACAGAGGAATGCGCCT- $3^{\prime}$; and $\beta$-actin, forward 5'-GATTACTGCTCTGGCTCCTAGCA-3', reverse $5^{\prime}$ GCTCAGGAGGAGCAATGATCTT. The lengths of the amplicons were 109 and $55 \mathrm{bp}$ respectively. For analysis, a threshold was set for the change in fluorescence at a point in the linear PCR amplification phase. The levels of DDC mRNA in tissues were normalized to $\beta$-actin and calculated using the SDS 2.1 software (Applied Biosystems), which relies on the comparative $C_{\mathrm{t}}$ method of quantification. At the end of the PCR, melting curves were performed to ensure that the specific amplification of the desired gene was achieved. Cycling conditions were set to 40 cycles at $95^{\circ} \mathrm{C}$ for $15 \mathrm{~s}$ and $60^{\circ} \mathrm{C}$ for $1 \mathrm{~min}$ (extension occurs in the temperature ramp between $60^{\circ} \mathrm{C}$ and $95^{\circ} \mathrm{C}$ ), with an initial step of $95^{\circ} \mathrm{C}$ for $10 \mathrm{~min}$.

\section{Western blot analysis}

Tissues were homogenized in $50 \mathrm{mM}$ Tris- $\mathrm{HCl}, \mathrm{pH} 8,1 \%$ Igepal, $1 \mathrm{mM}$ EDTA, and $0.1 \mathrm{mM}$ phenylmethylsulfonyl fluoride and centrifuged at $12000 \mathrm{~g}$ for $20 \mathrm{~min}$. In some cases, duodenum segments were homogenized in the same solution, containing an additional mixture of protease inhibitors (13 $\mu \mathrm{M}$ bestatin, 1.4 $\mu \mathrm{M}$ E-64, $100 \mu \mathrm{M}$ leupeptin, and $30 \mathrm{nM}$ aprotinin). Protein concentration was determined in the supernatant using Bradford reagent (Bio-Rad). Equal amounts of protein were mixed with Laemli sample buffer, heated at $95^{\circ} \mathrm{C}$ for $5 \mathrm{~min}$, and fractionated by electrophoresis in $10 \%$ polyacrylamide-SDS gels. The resolved proteins were electroblotted to polyvinylidene difluoride (PVDF) membranes, and the resulting blots were incubated with $5 \%$ non-fat dry milk in PBS (0.01 M PBS pH 7.4) for $1 \mathrm{~h}$. After washing in PBS + 0.1\% Tween 20 (PBST), the blots were incubated for $3 \mathrm{~h}$ at room temperature with rabbit polyclonal antibody against DDC (dilution 1:1000 in PBST; Calbiochem). The blots were washed with PBST and incubated overnight at $4{ }^{\circ} \mathrm{C}$ with a horseradish peroxidase-labeled secondary antibody (dilution 1:5000; Chemicon International Inc., Temecula, CA, USA). Immunoreactive bands were detected using $\mathrm{ECL}^{\mathrm{TM}}+$ detection reagent (Amersham Pharmacia Biotech) and commercial developing reagents and films (Amersham). For AR and estrogen receptor $(\mathrm{ER} \alpha)$ analyses, rabbit polyclonal antibodies obtained from Santa Cruz Biotechnology Inc. were used at a dilution of 1:500. As a control of equal loading, membranes were stripped and reprobed with $\beta$-actin biotinylated antibody (Santa Cruz Biotechnology Inc., Santa Cruz, CA, USA).

\section{Histology and immunocytochemistry}

Kidney and duodenum from male and female mice were removed and fixed in 10\% formalin in PBS for $10 \mathrm{~h}$. After washing in PBS, samples were processed routinely and cut into $5 \mu \mathrm{m}$ paraffin sections. Sections were stained with hematoxylin-eosin and immunocytochemistry. 
For immunocytochemistry, a two-step method was applied. Tissue sections from paraffin blocks were deparaffinized in xylene and hydrated in a graded ethanol series. Endogenous peroxidase activity was destroyed by treatment with $0 \cdot 3 \%$ hydrogen peroxide in PBS for $30 \mathrm{~min}$. Sections were washed with three $5 \mathrm{~min}$ changes of PBS and then incubated with normal goat serum (1:30) for $1 \mathrm{~h}$, and then with rabbit polyclonal antibody to DDC (Calbiochem, dilution 1:200) for $36 \mathrm{~h}$ at $4{ }^{\circ} \mathrm{C}$. After washing in PBS, they were incubated with peroxidase-conjugated goat anti-rabbit immunoglobulin (Chemicon International Inc., dilution 1:100) for $1 \mathrm{~h}$, and developed with 3,3-diaminobenzidine tetra hydrochloride and $0 \cdot 015 \%$ hydrogen peroxide. After immunostaining, sections were counterstained with hematoxylin. In controls, anti-DDC antibody was substituted by PBS.

\section{Statistical analysis}

Results are given as means \pm s.E.M. The significance of the differences observed was assessed by Student's t-test or ANOVA, followed by the post hoc Newman-Keuls multiple range test. $P<0 \cdot 05$ was considered statistically significant.

\section{Results}

Table 1 shows the influence of sex on the activity of DDC in different mouse tissues. Whereas in most tissues analyzed no differences in DDC activity between sexes were evident, in the kidney and in the small intestine a dimorphic and opposite pattern was found. DDC activity in the female kidney was approximately fivefold higher than in the male kidney, while the opposite was found in the small intestine. In both cases, the maximal values of DDC activity were similar to those found in the liver and the adrenal glands.

Table 1 Sexual dimorphism of 3,4-dihydroxyphenylalanine decarboxylase (DDC) activity in murine tissues. Results are means \pm S.E.M. of duplicates from five to eight animals per group

DDC activity ( $\mathrm{nmol} \mathrm{CO}_{2} / \mathrm{h}$ per g wet tissue)

\begin{tabular}{lcc}
\cline { 2 - 3 } Organ & & \\
Liver & $3200 \pm 452$ & $3410 \pm 340$ \\
Kidney & $636 \pm 81$ & $3247 \pm 350^{*}$ \\
Pancreas & $457 \pm 157$ & $533 \pm 189$ \\
Brain & $798 \pm 59$ & $853 \pm 109$ \\
Small intestine & $2174 \pm 980$ & $384 \pm 170^{*}$ \\
Heart & $310 \pm 112$ & $476 \pm 150$ \\
Adrenal gland & $2322 \pm 714$ & $2076 \pm 613$ \\
Skeletal muscle & $27 \pm 2$ & $21 \pm 3$ \\
Prostate & $42 \pm 14$ & - \\
Testis & $21 \pm 4$ & - \\
Ovary & - & $34 \pm 10$ \\
& &
\end{tabular}

Statistical significance: ${ }^{*} P<0 \cdot 001$ versus males.
To study the influence of sex hormones on this sexual dimorphism, both adult male and female mice were gonadectomized. Moreover, another group of castrated males were given $17 \beta$-estradiol benzoate for 2 weeks and adult intact females were treated with testosterone propionate for 15 days. As shown in Fig. 1A, renal DDC activity increased in the kidney of male mice after orchidectomy, although the values did not reach those found in the kidney of female mice. Treatment of castrated males with estradiol for a period of 2 weeks did not modify renal DDC activity. On the other hand, the repetitive treatment of female mice with testosterone propionate for 2 weeks elicited a marked decrease in renal DDC activity, approaching the values measured in the intact males. In the ovariectomized females, no significant changes in DDC activity were observed. Moreover, the timecourse analysis of renal DDC activity during the period of postnatal development showed that in both sexes there was a gradual increase in the enzyme activity between the second and fourth weeks of age, and that after puberty the activity markedly decreased in the males but steadily increased in the females (Fig. 1B). These results indicate that testosterone

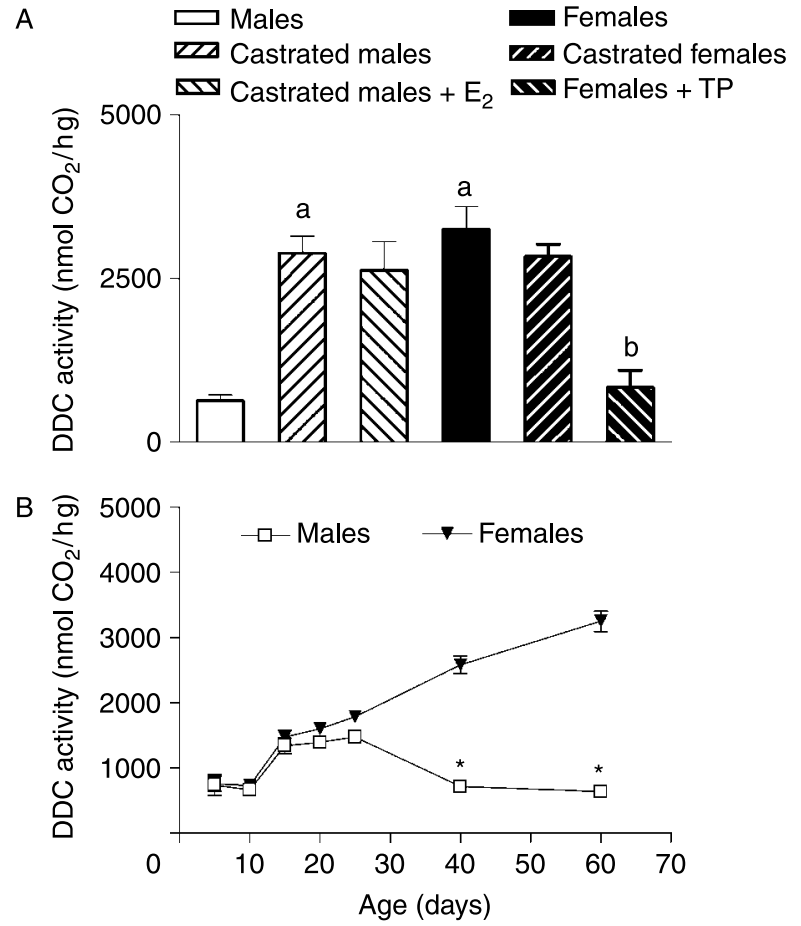

Figure 1 Sexual dimorphism of DDC activity in mouse kidney. (A) Renal DDC activity in adult male and female control, gonadectomized mice 15 days after castration, castrated male treated with $17 \beta$-estradiol benzoate $\left(E_{2}, 50 \mu \mathrm{g} / \mathrm{kg} \mathrm{BW}\right.$, sc, daily during 15 days), and intact females treated with testosterone propionate (TP, $20 \mathrm{mg} / \mathrm{kg} \mathrm{BW,} \mathrm{sc,} \mathrm{every} \mathrm{other} \mathrm{day} \mathrm{during} 15$ days). Results are means \pm S.E.M. of four to six animals per group. a, $P<0.001$ versus control males; $b, P<0.001$ versus control females. (B) Postnatal evolution of renal DDC activity in male and female mice. Each point represents means \pm S.E.M. of four animals per group. ${ }^{*} P<0 \cdot 001$. 
appears to be implicated in the regulation of renal DDC activity at least in CD1 mice.

Figure 2 shows that sex differences were also evident in intestinal DDC. Here, DDC activity was higher in males than in females in the three segments of the small intestine studied. Interestingly, no significant differences were observed in the colon. Moreover, in the castrated male, DDC activity decreased in all parts of the small intestine, reaching values similar to those found in females. Furthermore, the treatment of female mice with testosterone propionate, elicited a robust increase in DDC activity in duodenum and jejunum, which was weaker in the ileum and non-significant in the colon. Figure $3 \mathrm{~A}$ also shows that in the duodenum, like in the kidney, estrogen did not modify DDC activity, since castration of females or estradiol treatment of castrated males did not significantly affect the activity of this enzyme. The ontogenic study of DDC activity in the duodenum showed that after weaning there was an increase in DDC activity in both sexes, followed by a fall in the enzyme activity that was more marked in the females (Fig. 3B).

The analysis of the levels of DDC mRNA in kidney and duodenum by semiquantitative RT-PCR, revealed that there were differences in the expression of DDC between sexes, with the same tendency as the one observed with DDC activity (data not shown). No differences were observed in the size of the amplified fragments between the different groups analyzed. A more precise analysis by real-time RT-PCR confirmed that the levels of DDC mRNA in the kidney of females were about sixfold higher than in males (Fig. 4A). The analysis of DDC mRNA in castrated and hormone-treated animals also revealed significant changes that paralleled those found in DDC activity. The analysis of DDC mRNA in the duodenum also indicated that in this tissue the levels of DDC mRNA were slightly higher in the males than in the females, but that hormonal manipulation did not significantly affect mRNA expression. Moreover, there was not evident

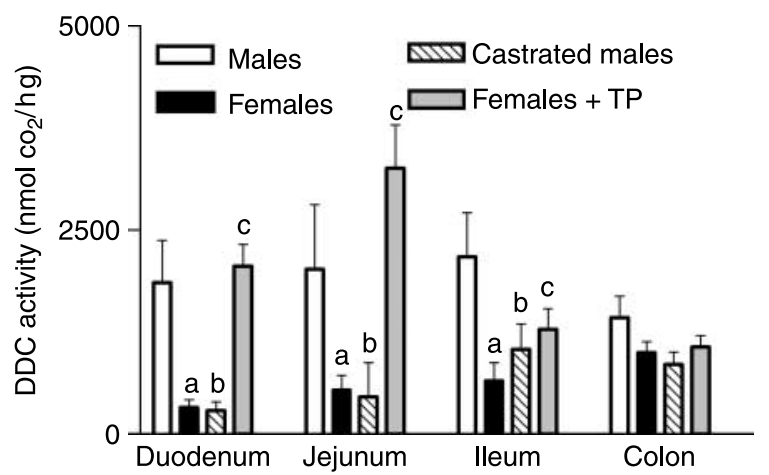

Figure 2 Sexual dimorphism of DDC activity in mouse intestine. DDC activity in different intestinal segments of adult male or female control, orchidectomized mice 15 days after castration, and female mice treated with testosterone propionate (TP, $20 \mathrm{mg} / \mathrm{kg} \mathrm{BW,} \mathrm{sc,}$ every other day during 15 days). Results are means \pm S.E.M. of four to six animals per group. a, $P<0.001$ versus control males; $b$,

$P<0.001$ versus intact males; $c, P<0.001$ versus control females.

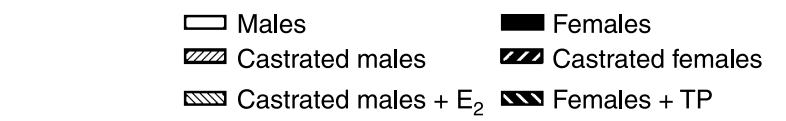

A

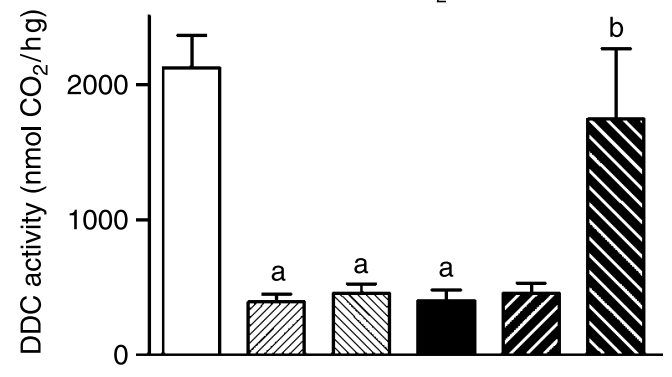

B

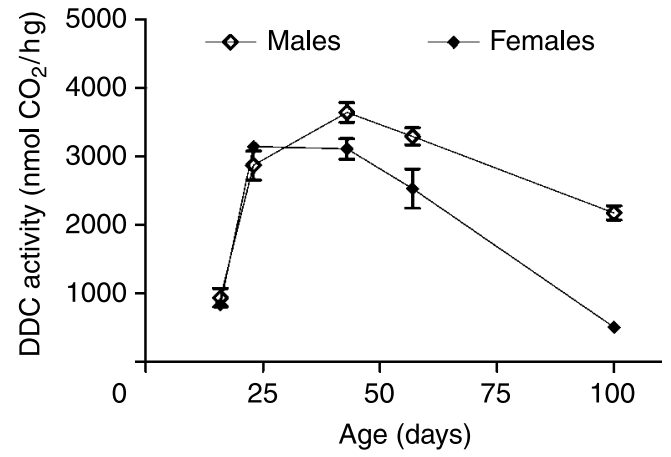

Figure 3 Sexual dimorphism of DDC activity in mouse duodenum. (A) DDC activity in the duodenum of adult male and female control, gonadectomized mice 15 days after castration, castrated male treated with $17 \beta$-estradiol benzoate $\left(\mathrm{E}_{2}, 50 \mu \mathrm{g} / \mathrm{kg} \mathrm{BW}\right.$, sc, daily during 15 days), and intact females treated with testosterone propionate (TP, $20 \mathrm{mg} / \mathrm{kg} \mathrm{BW,} \mathrm{sc}$, every other day during 15 days). Results are means \pm S.E.M. of four to six animals per group. $a$, $P<0.001$ versus control males; $b, P<0.001$ versus control females. (B) Postnatal evolution of duodenal DDC activity in male and female mice. Each point represents means \pm S.E.M. of four to six animals per group. ${ }^{*} P<0 \cdot 001$.

correlation with DDC activity (Fig. 4B). Figure 5 shows that the level of expression of DDC protein, assessed by western blotting, was higher in the kidney of female mice than in the male (about $2 \cdot 5$-fold, $P<0 \cdot 01$ ). This figure also indicates that in the duodenum, DDC protein levels were relatively higher in males than in females (about twofold, $P<0 \cdot 01$ ), in agreement with the results on DDC activity. In all groups, the molecular weight of the protein detected was identical, about $54 \mathrm{kDa}$, in agreement with the predicted size deduced from its amino acid sequence. As a whole, these results indicate that the differences in renal DDC activity found between sexes are related to parallel changes in DDC mRNA and DDC protein, while translational or posttranslational controls appear to participate in the regulation of duodenal DDC activity. Figure 5 also shows that ARs and ERs are expressed in both kidney and duodenum, females having a relatively higher level of expression than males.

In order to know the rate of response of renal DDC to androgens, male and female mice were treated respectively with the antiandrogen flutamide and with testosterone propionate 

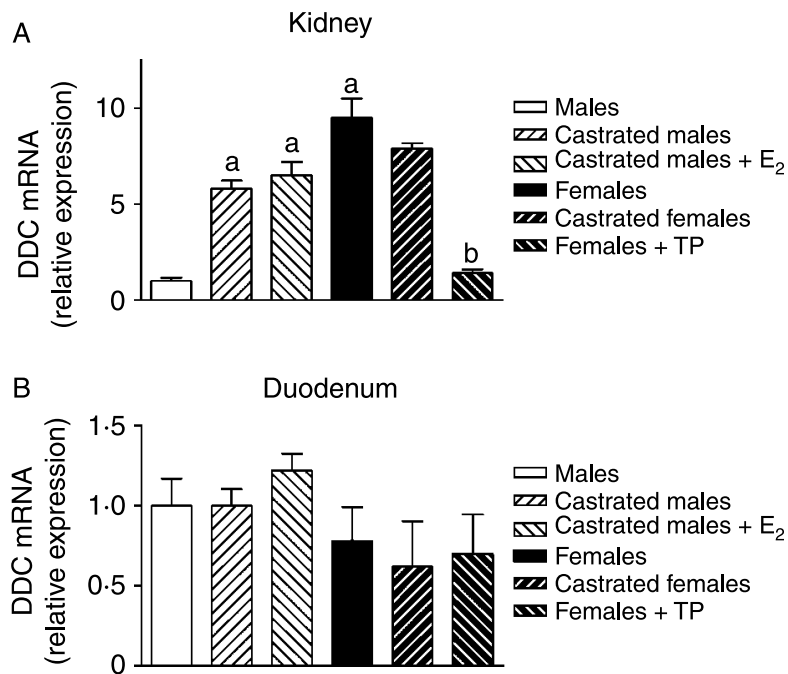

Figure 4 Influence of chronic exposure to sex hormones on DDC mRNA expression in the (A) kidney and (B) duodenum of mice. DDC mRNA was quantified by real-time RT-PCR from RNA samples obtained from kidney and duodenum of control male and female mice, gonadectomized mice 15 days after castration, castrated male treated with $17-\beta$ estradiol benzoate $\left(E_{2}, 50 \mu \mathrm{g} / \mathrm{kg} \mathrm{BW}\right.$, sc, daily during 15 days), and intact females treated with testosterone propionate (TP, $20 \mathrm{mg} / \mathrm{kg}$ BW, sc, every other day during 15 days). Results are means \pm s.E.M. of three animals per group. DDC mRNA levels were normalized with respect to those of $\beta$-actin and expressed as arbitrary units with respect to the value of control males that was taken as 1 . a, $P<0 \cdot 001$ versus control males; $b, P<0 \cdot 001$ versus control females.

for shorter periods of time (24 and $48 \mathrm{~h}$ ). Figure 6A shows that these treatments did not significantly affect renal DDC activity. However, the levels of DDC mRNA markedly changed in both cases, the antiandrogen inducing a significant increase of the mRNA (about fourfold) in the kidney of treated males and testosterone producing a marked decrease of the mRNA concentration in the kidney of the treated females that reached values about $30 \%$ of controls (Fig. 6B). This lack of

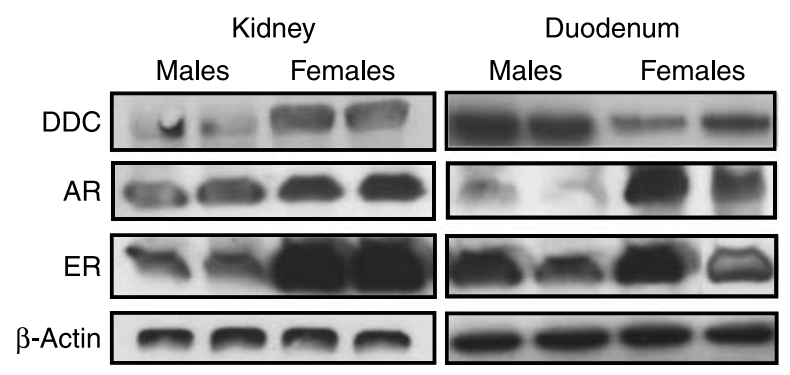

Figure 5 Western blot analysis of DDC, androgen receptor, and estrogen receptor in mouse kidney and duodenum of male and female mice. Representative samples from kidney and duodenum of male and female mice. DDC, DOPA decarboxylase; AR, androgen receptor; $E R$, estrogen receptor- $\alpha$. $\beta$-Actin was used as a loading control. For intestinal DDC, the bands from six males and six females were quantified by scanning densitometry. The values expressed in arbitrary units were $1 \cdot 00 \pm 0 \cdot 33$ for males and $0 \cdot 48 \pm 0 \cdot 09$ for females $(P<0 \cdot 01)$.
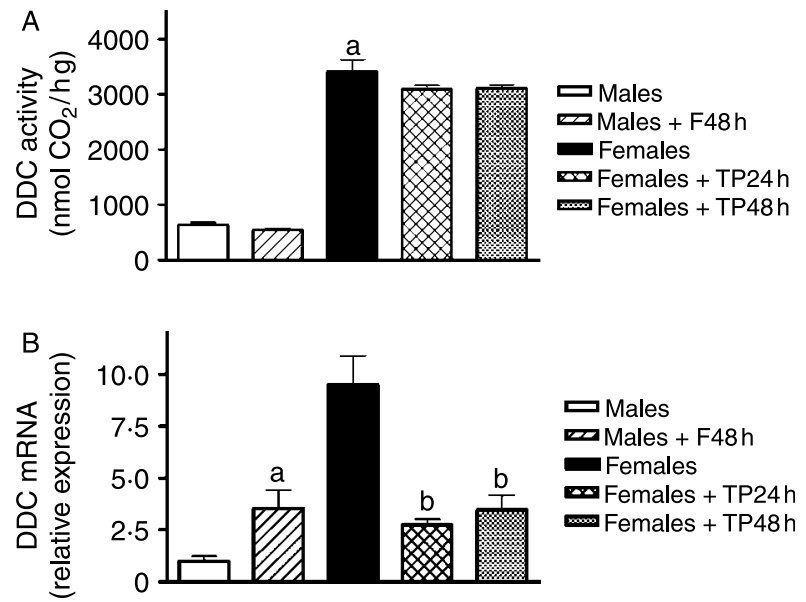

Figure 6 Acute effects of androgens and antiandrogens on DDC expression in the mouse kidney. (A) DDC activity. (B) DDC mRNA levels normalized with respect to $\beta$-actin. Male mice were injected sc with flutamide (F, $25 \mathrm{mg} / \mathrm{kg}$ BW, 4 injections, $12 \mathrm{~h}$ apart) and killed $48 \mathrm{~h}$ after the first injection. Female mice received a single sc injection of testosterone propionate (TP, $20 \mathrm{mg} / \mathrm{kg} \mathrm{BW}$ ) at $0900 \mathrm{~h}$ and were killed 24 or $48 \mathrm{~h}$ after injection. DDC mRNA levels were normalized with respect to those of $\beta$-actin and expressed as arbitrary units with respect to the value of control males in this tissue that was taken as 1 . a, $P<0.01$ versus control males; $b, P<0 \cdot 001$ versus control females.

correspondence between DDC activity and mRNA levels appears to be related with the slow turnover rate of the renal DDC, since in our hands renal DDC activity did not change after 10 or $24 \mathrm{~h}$ of cycloheximide treatment, in contrast to the dramatic decrease of renal ODC (results not shown).

To study the cellular localization of DDC in kidney and duodenum, DDC protein was detected by immunocytochemistry. Both male and female kidneys showed a similar immunolabeling pattern. Only proximal tubular cells were reactive to DDC antibodies. However, this reactivity was increased in the proximal straight tubular cells located in the outer stripe of the outer medulla (Fig. 7a). Proximal convoluted tubules showed light-to-moderate immunoreactivity to DDC antibodies, whereas no reaction was observed in distal tubules (Fig. 7c). In the proximal straight tubular cells, DDC immunoreactivity was lower in males (Fig. 7d) than in females (Fig. 7e). In the duodenum, DDC immunolabeling was detected in the cytoplasm of enterocytes. The reactivity was more intense in males (Fig. $7 \mathrm{f}$ and g) than in females (Fig. 7h). Some epithelial cells in deep crypts were also strongly reactive (Fig. 7f).

Since dopamine, a product of DDC, has been implicated in renal sodium handling in the rat (Vieira-Coelho et al. 2000), we decided to study the possible influence of DDC dimorphism in kidney on sodium renal absorption by measuring sodium levels in the urine of male and female mice. Table 2 shows that the relative sodium excretion in the urine of female mice was about $60 \%$ higher than in male mice. Moreover, in castrated male mice sodium urinary excretion increased, reaching values similar to those found in females, 

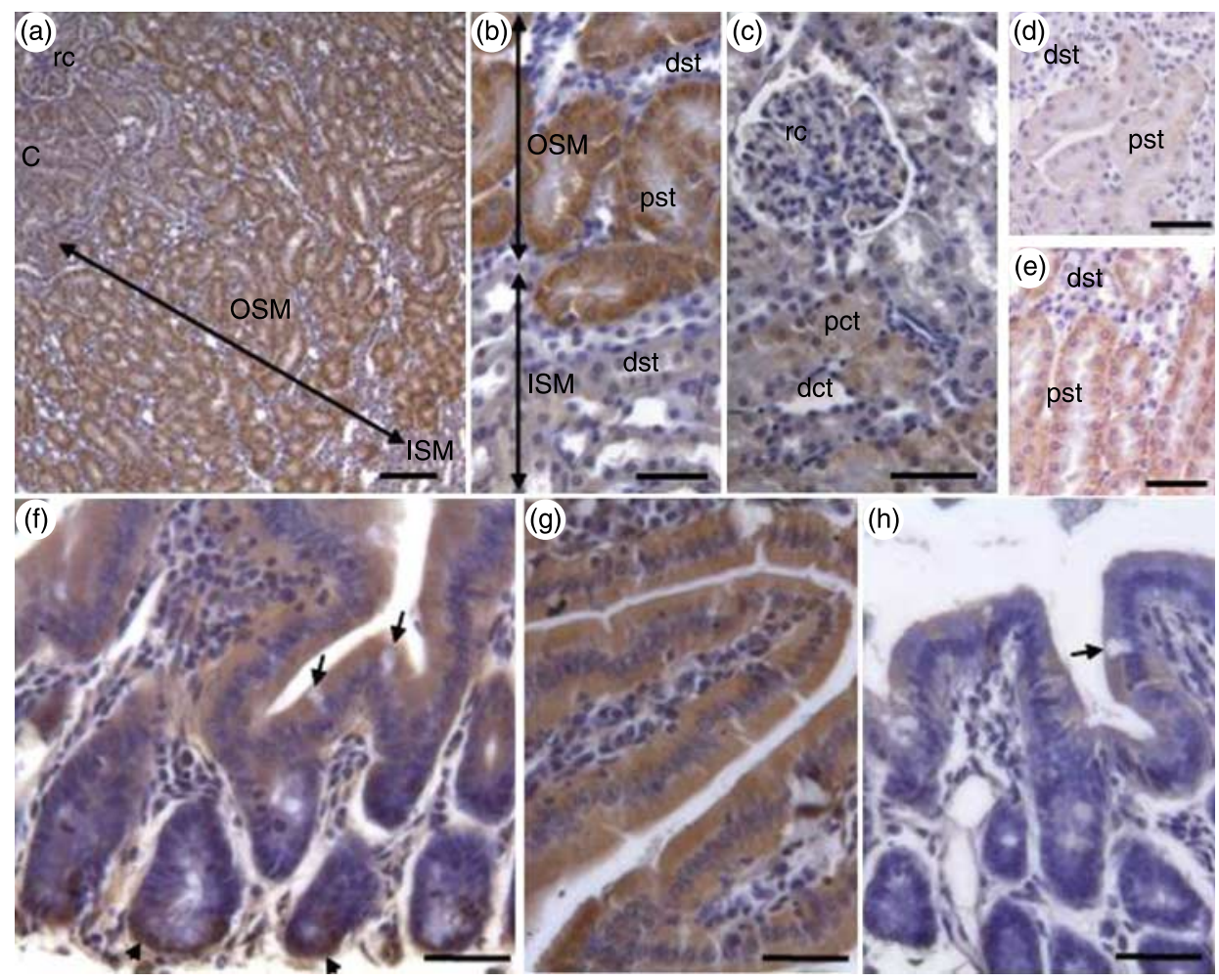

Figure 7 (a-e) Anti-DOPA decarboxylase immunolabeling in kidney and ( $\mathrm{f}-\mathrm{h}$ ) duodenum. (a) A lowmagnification picture showing the main reaction to DDC in the outer stripe of outer medulla of mouse kidney. (b) Note the highest intensity located in proximal straight tubular cells. (c) A slight or moderate labeling is observed in proximal convoluted tubules. C, cortex; OSM, outer stripe of outer medulla; ISM, inner stripe of outer medulla; rc, renal corpuscle; pst, proximal straight tubule; pct, proximal convoluted tubule; dst, distal straight tubule; dct, distal convoluted tubule. ( $d$ and e) Compare the DDC immunoreactivity of proximal straight tubule between (d) male and (e) female. ( $f$ and g) Note the intense labeling for DDC in enterocytes of male, while a slight reactivity is observed in female samples (h). No reaction is detected in goblet cells (arrows). A strong reaction is found in some epithelial cells of the deep crypts (arrowhead). Bars: $100 \mu \mathrm{m}(\mathrm{a}), 40 \mu \mathrm{m}(\mathrm{b}-\mathrm{h})$. Full colour version of this figure available via http://dx. doi.org/10.1677/JOE-07-0564

whereas the treatment of female mice with testosterone reduced sodium excretion (Table 2). As shown in this Table, potassium values in urine were not significantly different between sexes, and orchidectomy or testosterone treatment did not affect potassium excretion. These results indicate that

Table 2 Sodium and potassium levels in the urine of control and treated mice. Urine samples were collected by means of metabolic cages containing two animals per cage. Sodium, potassium, and creatinine levels were determined by duplicate in each sample. Results are means \pm S.E.M. and are expressed as $\mathrm{mEq} / \mathrm{mol}$ creatinine

\begin{tabular}{llll} 
& $\mathbf{N a}^{+}$ & $\mathbf{K}^{+}$ \\
\cline { 2 - 2 } Control males (10) & $14 \cdot 6 \pm 1 \cdot 8$ & & $78 \cdot 7 \pm 2 \cdot 3$ \\
Control females (10) & $23 \cdot 4 \pm 1 \cdot 6^{*}$ & & $79 \cdot 6 \pm 2 \cdot 6$ \\
Castrated males (6) & $29 \cdot 3 \pm 3 \cdot 1^{*}$ & & $82 \cdot 6 \pm 7 \cdot 6$ \\
Females +TP (6) & $13 \cdot 1 \pm 1 \cdot 2^{+}$ & & $77 \cdot 2 \pm 3 \cdot 2$
\end{tabular}

${ }^{*} P<0.001$ versus males, ${ }^{+} P<0.001$ versus control females. The number of animals in each group is given in brackets. there is an inverse correlation between DDC activity and sodium reabsorption in the kidney, confirming the hypothesis that dopamine may inhibit sodium absorption. Unfortunately, our attempts to measure $\mathrm{Na}^{+}$levels in mouse feces yielded non-reproducible results, presumably due to contamination of the feces with urine or small fragments of the pelleted chow that precluded the analysis of sodium absorption by the gut.

\section{Discussion}

The results presented here clearly demonstrate that there is a marked sexual dimorphism in DDC activity, affecting kidney and small intestine. To our knowledge, this is the first report showing the existence of DDC gender-dependent dimorphism in CD1 mice. Moreover, it is also shown that the DDC sexual dimorphism found in kidney and intestine is opposite, since female kidneys have higher DDC activity than male ones, whereas DDC activity in the small intestine is 
higher in the males. Our results on the effect of gonadectomy on renal and intestinal DDC activity, besides the influence of testosterone and estradiol treatments on DDC activity of kidney and small intestine, strongly suggest that androgens may play a relevant role in DDC sexual dimorphism. This influence of testosterone on DDC renal gender-dependent dimorphism is not surprising, since it has been very well known, for quite some time, that mouse kidney is an androgen-responsive organ (Bardin \& Catterall 1981, Berger \& Watson 1989). In this respect, a considerable number of genes, including $\beta$-glucuronidase, ODC, kidney androgenregulated protein, RP2, alcohol dehydrogenase, aldehyde oxidase, and arginase II, among others, have been shown to be up-regulated by androgens in the mouse kidney (Catterall et al. 1986, Berger \& Watson 1989, Melia et al. 1998, Kurosaki et al. 1999, Levillain et al. 2005). On the contrary, it is also known that some genes, such as testosterone $16 \alpha$-hydroxylase or ornithine aminotransferase, are down-regulated by androgens (Melia et al. 1998, Levillain et al. 2005).

According to our results, the androgen-mediated regulation of DDC expression in mice appears to be complex, since testosterone elicited inverse effects on the expression of this gene in kidney and small intestine. The fact that renal DDC activity and protein in male and female mice correlated well with the concentrations of DDC mRNA in the kidney, associated with the finding that androgen ablation and androgen treatment up-regulated and down-regulated respectively DDC expression, strongly supports the possibility that in the kidney, testosterone may control DDC gene expression at the level of mRNA, either controlling DDC gene transcription or DDC mRNA stability. The lack of effect of estrogen manipulations on renal DDC expression suggests that this hormone has little effect on DDC regulation. On the other hand, in the small intestine, the absence of a precise correlation between DDC mRNA levels and DDC activities between sexes suggests that translational or post-translational mechanisms, rather than transcriptional control, may be implicated in the regulation of intestinal DDC.

The existence of ARs in the kidney and intestine of different mammals, including mice, is well documented (Pajunen et al. 1982, Quinkler et al. 2005, González-Montelongo et al. 2006). Our results on receptor analysis confirm the presence of ARs in the kidney and small intestine of both sexes, and that ERs are also expressed in these tissues. However, in our case, it cannot be ascertained whether the effects of androgens on DDC expression are primary effects of the hormone on DDC gene or secondary effects resulting from steroid action at other sites. Despite that it is known that murine DDC is encoded by a single gene located on chromosome 11, to our knowledge no androgen response elements have been identified within or in the flanking regions of the DDC gene. The opposite effect of testosterone on DDC gene expression found in kidney and intestine could be related, in principle, with differences in the set of nuclear receptor co-repressors or co-activators or in other tissue-specific factors, as well as in epigenetic changes that may affect androgen action. In this regard, it must be noted that opposite effects of testosterone on other amino acid decarboxylases, such as ODC, have been also observed in different mouse tissues, where androgens dramatically increased this enzyme in the kidney but down-regulated ODC in the mouse adrenals (Bastida et al. 2007). Furthermore, our results on the effect of androgens on renal DDC are in agreement with recent studies that concluded that human neoplastic prostate epithelium DDC is down-regulated by androgens (Nelson et al. 2002).

The study on the cellular localization of DDC in kidney and small intestine, the tissues showing DDC genderdependent dimorphism, may be of interest in order to postulate the possible physiological relevance of DDC sex dimorphism. Our finding that DDC is mainly located in the proximal tubular cells of the kidney is in agreement with a recent report claiming that both DDC mRNA and DDC immunoreactive protein are expressed in the mouse kidney cortex (Kubovcanova et al. 2004). Moreover, our results showing differences in urinary sodium excretion between sexes support the possibility that sex differences in dopamine production, caused by the gender dependence of DDC activity in the epithelial cells of the proximal tubule, may affect renal sodium reabsorption between sexes. This assumption is in agreement with studies that reveal that dopamine and D1-receptor agonists inhibit sodium transport mechanisms such as $\mathrm{Na}^{+} / \mathrm{K}^{+}$ATPase at the basolateral membrane (Aperia et al. 1987, Seri et al. 1990) and $\mathrm{Na}^{+} / \mathrm{H}^{+}$ exchanger at the apical membrane (Felder et al. 1990, Gomes \& Soares-da-Silva 2004), or that testosterone may promote sodium reabsorption by stimulating $\mathrm{Na}^{+} / \mathrm{H}^{+}$pumps (Mackovic et al. 1986, Quinkler et al. 2005).

Our results on intestinal DDC could be also related to gender differences in sodium levels in the feces, since both the localization of DDC in the epithelial cells of the small intestine and the higher values of DDC activity found in the males could be consistent in principle with reduced sodium absorption by the male gut. In fact, it has been reported that in young rats fed with a high-salt diet, jejunal $\mathrm{Na}^{+} / \mathrm{K}^{+}$ATPase is inhibited, likely by the action of locally formed dopamine (Vieira-Coelho et al. 1998). Moreover, decreased jejunal absorption of sodium may take place in response to partial renal ablation (Vieira-Coelho et al. 2000). Therefore, a greater inhibition of $\mathrm{Na}^{+}$uptake in the intestinal mucosa of male mice, as a consequence of a higher dopamine production, could be associated with relatively higher levels of $\mathrm{Na}^{+}$in the feces of male mice. Unfortunately, this hypothesis could not be confirmed, since the estimation of sodium levels in the feces, in our hands, yielded non-reproducible results. On the other hand, to explain our results on the influence of androgens on DDC activity in the small intestine, one possibility is that testosterone, as pointed out before, may directly interact with ARs located in the target cells leading to DDC induction. Our results indicate that both ARs and ERs are expressed in the duodenum of male and female mice, although this does not demonstrate that sex dimorphism of intestinal DDC is related to the direct action of testosterone on DDC expression in this 
tissue that, unlike in the kidney, appears to be exerted at posttranscriptional level. In fact, an alternate view on the effect of this hormone on intestinal DDC is that it may be secondary to its action on the kidney. This possibility seems to be consistent with the existence of a renal-intestinal crosstalk, as it was earlier suggested (Vieira-Coelho et al. 2000), although the mechanisms that support this possibility are far from being understood. The fact that in our ontogeny studies (Figs 2B and 4B) DDC sex dimorphism in the duodenum appears to be delayed with respect to that found in the kidney could also support the hypothesis that primary changes in DDC in the kidney may affect later the expression of this enzyme in the intestine.

In conclusion, our results reveal the existence of a marked and opposite sexual dimorphism in DDC activity in mice kidney and small intestine, which might be related with differences in $\mathrm{Na}^{+}$reabsorption by the renal tubules and mucosa cells of the small intestine. Such differences may have implications for sex-specific etiology and treatment of diseases related with these parameters, such as hypertension or renal injury, and in the sex-dependent bias observed in the response to treatments with dopaminergic drugs.

\section{Acknowledgements}

This work was supported by grants 00466/PI/04 from 'Fundación Séneca' (Autonomous Community of Murcia) and BFU2005-09378-C02 from the Spanish Ministry of Education. A J L-C is recipient of a pre-doctoral fellowship from 'Fundación Séneca'. The authors declare that there is no conflict of interest that would prejudice the impartiality of this scientific work.

\section{References}

Aperia A, Bertorello A \& Seri I 1987 Dopamine causes inhibition of $\mathrm{Na}^{+}$ $\mathrm{K}^{+}$-ATPase activity in rat proximal convoluted tubule segments. American Journal of Physiology. Renal Physiology 252 F39-F45.

Bardin CW \& Catterall JF 1981 Testosterone: a major determinant of extragenital sexual dimorphism. Science 211 1285-1294.

Bastida CM, Cremades A, Castells MT, López-Contreras AJ, López-García C, Tejada F \& Peñafiel R 2005 Influence of ovarian ornithine decarboxylase in folliculogenesis and luteinization. Endocrinology 146 666-674.

Bastida CM, Cremades A, Castells MT, Lopez-Contreras AJ, Lopez-García C, Sanchez-Mas J \& Penafiel R 2007 Sexual dimorphism of ornithine decarboxylase in the mouse adrenal: influence of polyamine deprivation on catecholamine and corticoid levels. American Journal of Physiology. Endocrinology and Metabolism 292 E1010-E1017.

Berger FG \& Watson G 1989 Androgen-regulated gene expression. Annual Review of Physiology 51 51-65.

Berry MD, Juorio AV, Li X \& Boulton AA 1996 Aromatic L-amino acid decarboxylase: a neglected and misunderstood enzyme. Neurochemical Research 21 1075-1087.

Bertorello A, Hofkelt T, Goldstein M \& Aperia A 1988 Proximal tubule $\mathrm{Na}^{+}$$\mathrm{K}^{+}$-ATPase activity is inhibited during high salt diet: evidence for DA-mediated effect. American Journal of Physiology. Renal Physiology 254 F795-F801.

Borri Voltattorni C, Minelli A, Vecchini P, Fiori A \& Turano C 1979 Purification and characterization of 3,4-dihydroxyphenylalanine decarboxylase from pig kidney. European Journal of Biochemistry 93 181-188.
Carlsson A 1987 Perspectives on the discovery of central monoaminergic neurotransmission. Annual Review of Neuroscience 10 19-40.

Catterall JF, Kontula K, Watson C, Seppanen P, Fukenstein B, Melatinou E, Hickok N, Bardin CW \& Jänne OA 1986 Regulation of gene expression by androgens. Recent Progress in Hormone Research 42 71-109.

Christenson JG, Dairman W \& Udenfriend S 1972 On the identity of Dopa decarboxylase and 5-hydroxytryptophan decarboxylase. PNAS 69 343-347.

Dominici P, Tancini B \& Borri Voltattorni C 1985 Chemical modification of pig kidney 3,4-dihydroxyphenylalanine decarboxylase with diethyl pyrocarbonate. Journal of Biological Chemistry 260 10583-10589.

Dominici P, Moore PS \& Borri Voltattorni C 1993 Dissociation, unfolding and refolding trials of pig kidney 3,4-dihydroxyphenylalanine (Dopa) decarboxylase. Biochemical Journal 295 493-500.

Felder CC, Campbell T, Albrecht F \& Jose PA 1990 Dopamine inhibits $\mathrm{Na}^{+}{ }_{-}$ $\mathrm{H}^{+}$exchanger activity in renal BBMV by stimulation of adenylate cyclase. American Journal of Physiology. Renal Physiology 259 F297-F303.

Fellman JH 1959 Purification and properties of adrenal L-DOPA decarboxylase. Enzymologia 20 366-376.

Gomes P \& Soares-da-Silva P 2004 Dopamine acutely decreases type 3 $\mathrm{Na}(+) / \mathrm{H}(+)$ exchanger activity in renal OK cells through the activation of protein kinases A and C signalling cascades. European Journal of Pharmacology 488 51-59.

González-Montelongo MC, Marín R, Gómez T \& Díaz M 2006 Androgens differentially potentiate mouse intestinal smooth muscle by nongenomic activation of polyamine synthesis and rho kinase activation. Endocrinology $1475715-5729$

Grahn B, Henningsson S, Kahlson G \& Rosengren E 1973 Alterations in the activities of ornithine decarboxylase and histidine decarboxylases provoked by testosterone in mice. British Journal of Pharmacology 48 113-120.

Hayashi H, Wada H, Yoshimura T, Esaci N \& Soda K 1990a Recent topics in pyridoxal 5'-phosphate enzyme studies. Annual Review of Biochemistry $\mathbf{5 9}$ $87-110$.

Hayashi M, Yamaji Y, Kitajima W \& Saruta T 1990b Aromatic L-amino acid decarboxylase activity along the rat nephrone. American Journal of Physiology. Renal Physiology 258 F28-F33.

Henningsson S, Persson L \& Rosengren E 1978 Polyamines and nucleic acids in the mouse kidney induced to growth by testosterone propionate. Acta Physiologica Scandinavica 102 385-393.

Hodgetts RB \& O'Keefe SL 2006 Dopa decarboxylase: a model gene-enzyme system for studying development, behaviour, and systematics. Annual Review of Entomology 51 259-284.

Ichinose H, Kurosawa Y, Titán K, Fujita K \& Nagatsu T 1989 Isolation and characterization of a cDNA clone encoding human aromatic L-amino acid decarboxylase. Biochemical and Biophysical Research Communications 164 1024-1030.

Kidron H, Repo S, Jonson M \& Salminen T 2007 Functional classification of amino acid decarboxylases from the alanine racemase structural family by phylogenetic studies. Molecular Biology and Evolution 24 78-79.

Kontula KK, Torkkeli TK, Bardin CW \& Jänne OA 1984 Androgen induction of ornithine decarboxylase mRNA as studied by complementary DNA. PNAS 81 731-735.

Kubovcanova L, Krizanova O \& Kvetnansky R 2004 Identification of the aromatic L-amino acid decarboxylase gene expression in various mice tissues and its modulation by immobilization stress in stellate ganglia. Neuroscience $126375-380$.

Kurosaki M, Demontis S, Barzago MM, Garattini E \& Terao M 1999 Molecular cloning of the cDNA coding for mouse aldehyde oxidase: tissue distribution and regulation in vivo by testosterone. Biochemical Journal $\mathbf{3 4 1}$ $71-80$.

Levillain O, Diaz JJ, Blanchard O \& Dechaud H 2005 Testosterone downregulates ornithine aminotransferase gene and up-regulates arginase II and ornithine decarboxylase genes for polyamine synthesis in the murine kidney. Endocrinology 146 960-969.

Lindström P 1986 Aromatic L-amino-acid decarboxylase activity in mouse pancreatic islets. Biochimica et Biophysica Acta 884 276-281.

Lovenberg W 1971 Aromatic L-amino acid decarboxylase (guinea pig kidney). Methods in Enzymology XVIIB 652-656. 
De Luca M, Roshina NV, Geiger-Thornsberry GL, Lyman RF \& Pasynkova EG 2003 Dopa decarboxylase (Ddc) affects variation in Drosophila longevity. Nature Genetics 34 429-433.

Mackovic M, Zimolo Z, Burckhardt G \& Sabolic I 1986 Isolation of renal brush-border membrane vesicles by a low-speed centrifugation; effect of sex hormones on $\mathrm{Na}^{+}-\mathrm{H}^{+}$exchange in rat and mouse kidney. Biochimica et Biophysica Acta 862 141-152.

Marts SA \& Keitt S 2004 Foreword: a historical overview of advocacy for research in sex-based biology. In Principles of Sex-Based Differences in Physiology, vol 34, pp v-xiii. Eds V Millar \& M Hay. Amsterdam: Elsevier.

Melatinou E, Cohn DA, Bardin CW \& Jänne OA 1987 Genetic variation in androgen regulation of ornithine decarboxylase gene expression in inbred strains of mice. Molecular Endocrinology 1 266-273.

Melia MJ, Bofill M, Hubak M \& Meseguer A 1998 Identification of androgen regulated genes in mouse kidney by representational difference analysis and random arbitrarily primed polymerase chain reaction. Endocrinology 139 688-695.

Middleton RF \& Bulfield G 1988 Steroid regulation of kidney histidine decarboxylase and ornithine decarboxylase levels in mouse kidney: effects of the mutation testicular feminization, Tfm. Comparative Biochemistry and Physiology, Part B 90 221-225.

Middleton RF, Martin SA \& Bulfield G 1987 A new regulatory gene in the histidine decarboxylase gene complex determines the responsiveness of the mouse kidney enzyme to testosterone. Genetical Research 49 61-67.

Minelli A, Charteris AT, Borri Voltattorni C \& John RA 1979 Reactions of DOPA (3,4-dihydroxyphenylalanine) decarboxylase with DOPA. Biochemical Journal 183 361-368.

Molinoff PB \& Axelrod J 1971 Biochemistry of catecholamines. Annual Review of Biochemistry 40 465-500.

Moya-Garcia AA, Medina MA \& Sánchez-Jiménez F 2004 Mammalian histidine decarboxylase: from structure to functions. BioEssays 27 57-63.

Nelson PS, Clegg N, Arnold H, Fetguson C, Bonham M, White J, Hood L \& Lin B 2002 The program of androgen-responsive genes in neoplastic prostate epithelium. PNAS 99 11890-11895.

O'Learly MH \& Baughn RL 1977 Decarboxylation-dependent transamination catalyzed by mammalian 3,4-dihydroxyphenylalanine decarboxylase. Journal of Biological Chemistry 252 7168-7173.

Pajunen AEI, Isomaa VV, Jänne OA \& Bardin CW 1982 Androgenic regulation of ornithine decarboxylase activity in mouse kidney and its relationship to changes in cytosol and nuclear androgen receptor concentrations. Journal of Biological Chemistry 257 8190-8198.

Pegg AE 2006 Regulation of ornithine decarboxylase. Journal of Biological Chemistry 281 14529-14532.

Peñafiel R, Solano-Muñoz F \& Monserrat F 1983 Creatinine determination in dried urine on filter paper. Clinica Chimica Acta 127 289-293.

Da Prada M 1985 Peripheral decarboxylase inhibition: a biochemical comparison between benserazide and carbidopa. In Parkinson's Disease. Actual Problems and Management, pp 25-38. Ed. E Birkmayer. Basel: Editiones Roche.

Quinkler M, Bujalska IJ, Kaur K, Onyimba CU, Buhner S, Allolio B, Hughes SV, Hewison M \& Stewart PM 2005 Androgen receptor-mediated regulation of the $\alpha$-subunit of the epithelial sodium channel in human kidney. Hypertension 46 787-798.
Rahman MK, Nagatsu T \& Kato T 1981 Aromatic L-amino acid decarboxylase activity in central and peripheral tissues and serum of rats with L-Dopa and L-5-hydroxytryptophan as substrates. Biochemical Pharmacology 30 645-649.

Sánchez-Capelo A, Peñafiel R, Tovar A, Galindo JD \& Cremades A 1994 Postnatal development of ornithine decarboxylase and polyamines in the mouse kidney: influence of testosterone. Biology of the Neonate 66 $119-127$.

Sandmeier E, Hale T \& Christen P 1994 Multiple evolutionary origin of pyridoxal-5'-phosphate-dependent amino acid decarboxylases. European Journal of Biochemistry 221 997-1002.

Seely JE, Pösö H \& Pegg AE 1982 Effect of androgens on turnover of ornithine decarboxylase in mouse kidney. Journal of Biological Chemistry 257 7549-7553.

Seri I, Kone BC, Gullans SR, Aperia A, Brenner BM \& Ballermann BJ 1990 Influence of $\mathrm{Na}^{+}$intake on dopamine-induced inhibition of renal cortical $\mathrm{Na}^{+}-\mathrm{K}^{+}$-ATPase. American Journal of Physiology. Renal Fluid Electrolyte Physiology 258 F52-F60.

Siaterli MZ, Vassilacopoulou D \& Fragoulis EG 2003 Cloning and expression of human placental L-Dopa decarboxylase. Neurochemical Research $\mathbf{2 8}$ 793-803.

Tanaka T, Horio Y, Taketoshi M, Imamura I, Ando-Yamamoto M, Kanegawa K, Kuroda M \& Wada H 1989 Molecular cloning and sequencing of a cDNA of rat dopa decarboxylase: partial amino acid homologies with other enzymes synthesizing catecholamines. PNAS 78 5225-5229.

Vieira-Coelho MA, Lucas Teixeira VA, Finkel Y, Soares-da-Silva P \& Bertorello AM 1998 Dopamine-dependent inhibition of jejunal $\mathrm{Na}^{+}{ }_{-}$ $\mathrm{K}^{+}$-ATPase during high salt diet in young but not in adult rats. American Journal of Physiology. Gastrointestinal and Liver Physiology 275 G1317-G1323.

Vieira-Coelho MA, Serrao P, Guimaraes JT, Pestana M \& Soares-da-Silva P 2000 Concerted action of dopamine on renal and intestinal $\mathrm{Na}^{+}-\mathrm{K}^{+}{ }_{-}$ ATPase in the rat remnant kidney. American Journal of Physiology. Renal Physiology 279 F1033-F1044.

Viguera E, Trilles O, Urdiales JL, Mates JM \& Sanchez-Jimenez F 1994 Mammalian L-amino acid decarboxylases producing 1,4-diamines: analogies among differences. Trends in Biochemical Sciences 19 318-319.

Wafa LA, Cheng H, Nelson CC, Cox M, Hirst M, Sadowski I \& Rennie PS 2003 Isolation and identification of L-dopa decarboxylase as a protein that binds to and enhances transcriptional activity of the androgen receptor using the repressed transactivator yeast two-hybrid system. Biochemical Journal 375 373-383.

Zhu MY \& Juorio AV 1995 Aromatic L-amino acid decarboxylase: biological characterization and functional role. General Pharmacology 26 681-696.

Received in final form 12 December 2007

Accepted 19 December 2007

Made available online as an Accepted Preprint 19 December 2007 